Kansas State University Libraries

New Prairie Press

\title{
STUDYING HERBICIDE RESISTANCE USING TREATMENT AREA DYNAMICS MODEL
}

Agam N. Sinha

Dale L. Shaner

Follow this and additional works at: https://newprairiepress.org/agstatconference

Part of the Agriculture Commons, and the Applied Statistics Commons

\section{(c) (1) $\Theta(9$}

This work is licensed under a Creative Commons Attribution-Noncommercial-No Derivative Works 4.0 License.

\section{Recommended Citation}

Sinha, Agam N. and Shaner, Dale L. (1992). "STUDYING HERBICIDE RESISTANCE USING TREATMENT AREA DYNAMICS MODEL," Conference on Applied Statistics in Agriculture. https://doi.org/10.4148/ 2475-7772.1392

This is brought to you for free and open access by the Conferences at New Prairie Press. It has been accepted for inclusion in Conference on Applied Statistics in Agriculture by an authorized administrator of New Prairie Press. For more information, please contact cads@k-state.edu. 


\title{
STUDYING HERBICIDE RESISTANCE USING TREATMENT AREA DYNAMICS MODEL
}

Agam N. Sinha, Ph.D, Principal Statistician

Dale L. Shaner, Ph.D, Research Fellow

American Cyanamid Co., Princeton, N. J. 08543

\begin{abstract}
Repeated use of a herbicide or herbicides with the same mode of action on a particular crop over a number of years may cause the selection of herbicide resistant weed populations. As a result effective weed control is lost which can seriously affect crop yield and quality. The selection of herbicide resistant weed populations is a concern not only for crop-growers, but also the manufacturers of the affected herbicides. In the present paper a two-step procedure is developed to identify the herbicide resistant activity in a particular crop growing region by estimating the resistant areas (in acres/hectares) in a given year of herbicide continued treatment along with percent risk of detecting herbicide resistance. A computer aided treatment area dynamics model (TADM) for estimating resistant areas, and a multistage model for estimating risk of herbicide resistance are discussed. An example is presented at the end to illustrate the two-step procedure.
\end{abstract}

Keywords: treatment area dynamics, rotational pattern, risk, multistage model.

\section{INTRODUCTION}

Repeated use of a herbicide or herbicides with the same mode of action on a particular crop over a number of years has caused resistant weed populations. Some of these populations developed resistance to newer herbicides soon after their introduction (LeBaron, 1991). Chlorsulfuron was introduced for weed control in cereals in 1982 in the western United States. In 1987 Thill, et. al. (1991) discovered prickly lettuce populations near Lewiston, Idaho which were resistant to the sulfonylureas. Since then other sulfonylurea resistant populations including kochia (Kochia scoparia L. Schrad \# KOCSC), common chickweed (Stellaria media L. Vill \# STEME), and russian thistle (Salsola iberica Sennan \& Pau \# SALIB) have developed (Thill, et. al., 1991). Powles, et. al. (1990) reported that there are populations 
of rigid ryegrass (Lolium rigidium L. \# LOLRI) in Australia which are resistant to several different classes of herbicides. One population reportedly developed resistance to diclofop after only 4 applications.

The relatively rapid selection of resistant weed populations to new, highly efficacious herbicides indicate the need for establishing strategies early in the development of a new herbicide to prevent the selection for resistant weed biotypes. Although certain strategies, such as crop rotation with a concomitant rotation in weed control practices, tank mixes or sequential applications of herbicides with different modes of action, and integration of chemical weed control with mechanical, cultural and biological weed control practices are well understood, it has been difficult to know how effective these strategies will be before a herbicide is introduced into the market.

To try to predict how rapidly a new herbicide will select resistant weed populations, several biological models have been developed (Gressel, 1991; Maxwell, et. al., 1990). These models use different biological genetic and ecological data (i.e., the initial frequency of the resistant trait within the population, the fitness of the resistant biotypes, the reproductive capacity of the species and selective pressure of the herbicide) to estimate how rapidly the herbicide resistant trait will increase in a population. Although these models are very useful, their application is limited due to the lack of basic information on weed biology and ecology. Another limitation of these models is that they only predict which weeds might develop resistance, but not where those resistant populations are most likely to arise.

The location where a resistant population develops depends on the use pattern of the herbicide including the area treated with a herbicide, the crops on which a herbicide is used, and the rotation or tank mixing of a herbicide with other herbicides with different or similar modes of action. The objective of the present paper is to present a computer aided dynamic model to estimate the cumulative area at a given time (or year) which would have received a certain number of herbicide applications over a designated period of time (years), and then to estimate the associated risk of herbicide resistance. The mechanism of the model which is labeled here Treatment Area Dynamics is discussed in section 2. Section 3 describes the procedure for evaluating the risk of herbicide resistance, and an example is given in section 4 . 


\section{TREATMENT AREA DYNAMICS}

Treatment area dynamics (TAD) pertains to the dynamic allocation of areas in a two-way decision model to herbicide application in a region based on herbicide rotational pattern and the herbicide market share in that region. The basic assumptions of TAD are as follows:

1. The initial allocation of area (in acres/hectares) to the herbicide is always known;

and

2. The rotational pattern for subsequent herbicide applications are known for the region.

The rotational pattern in the two-way (with or without the herbicide) decision tree model is a quadruplet of proportions, namely, $P_{11}, P_{12}, P_{21}$, and $P_{22}$, where $P_{i j}$ is the proportion of area going from herbicide $i$ to herbicide $j$, and it is assumed that

$$
P_{i j}(\text { for } i \neq j)=1-P_{i i}
$$

The subscript $i, j$ in the following discussions can have two values as follow:

$i, j=1$ means that the allocation is to herbicide "A" of interest;

$=2$ means that the allocation is either to no herbicide or some other herbicide, other than "A".

These proportions may vary from one application time to another, or may be constant over a given period of herbicide application (for example say, 3 or 5 years). It should be noted that if the herbicide "A" is efficient and shows no adverse effect, the rotational pattern will remain constant at each subsequent application. On the other hand, if the herbicide "A" starts showing problems after a few repeated application, the proportional allocation of area to the herbicide "A" will decrease over the subsequent applications of the herbicide. In the next section, method of multistage modelling will be described to evaluate risk (in \%) associated with a specified number of applications of the herbicide "A" over a specified period of time. 


\subsection{DISTRIBUTION OF AREA UNDER HERBICIDE TREATMENT BY APPLICATION NUMBER}

Let $A$ denote the herbicide of interest and $B$ denote some other herbicide (other than A) or no herbicide. Also let

$$
\mathrm{Y}_{i j}=\begin{aligned}
& \text { Area under herbicide treatment at the } j^{\text {th }} \\
& \text { application coming from the } i \text { th application }
\end{aligned}
$$

The diagram given in figure 1 illustrates the flow of areas in subsequent applications of the herbicide based on the rotational pattern, $\mathrm{P}_{i j}$ 's. It is assumed that after the first application, an area equal to $\mathrm{Y}_{i}$ is added as a result of some efficient marketing strategies adopted by the maker of the herbicide, where $\mathrm{Y}_{11}$ is the starting area.

The distribution of area at different applications is given in Table 1.

\subsection{AREA UNDER EXPOSURE OF HERBICIDE WITH "a" OR MORE APPLICATIONS OVER A PERIOD OF " $n$ " YEARS}

Generally the herbicides are used for major crops like corn, wheat, soybean, cotton, etc... These crops may be grown every year or may be rotated every year. The herbicide treatment therefore is conducted in the field annually. With the herbicide treatment repeated over "n" years, we shall obtain expressions for area receiving just "a" number of herbicide applications, where $a \leq n(>1)$.

Consider the layout in figure 1. The starting area receiving herbicide application, i.e. in year 1 is $\mathrm{Y}_{11}$, and the new area additions starting from year 2 are $\mathrm{Y}_{22}, \mathrm{Y}_{33}$, $\mathrm{Y}_{44}$, etc... in the 2 nd, $3 \mathrm{rd}, 4 \mathrm{th}$, etc.. year respectively. From figure 1 we create Table 2. Computation of areas with a given number of herbicide applications over a given number of years thus becomes lengthy after year 4; however the logic is simple to understand. The computer has been used at this point to compute the areas with user specified input on "a", "n", and $P_{i j}$ 's. The computer program HRMODEL written in FORTRAN on VAX compute these areas at user's specification. An example is given in section 4. 


\section{RISK ASSESSMENT USING MULTISTAGE MODEL}

Risk of selection of weed populations resistant to a herbicide increases with repeated use of the herbicide in a region. How much a herbicide is creating resistance in weed populations in a particular crop in a region is also reflected in the rotational pattern ( $P_{i j}{ }^{\prime} s$ ) over the years. A slight decrease in the values of $\mathrm{P}_{11}$ and/or $\mathrm{P}_{21}$ used in that region over subsequent years may result in significant decreased in the area exposed to "a" or more number of herbicide treatments over a period of "n" years compared to a constant values of $P_{11}$ and $P_{21}$ over the years, where $a \leq n$ is a positive integer greater than 1. The intent of this section is to assess the risk of herbicide resistance in a quantifiable term associated with a region which would have received or has received "a" or more herbicide applications over a period of "n" years. It is assumed here (as is the practice) that an application of a herbicide is made on a yearly basis.

It can be assumed without any loss of generality that rates of occurrence of resistance brought in by " $m$ " changes $(\mathrm{m}=\mathrm{a}-$ 1), 'a' being the number of herbicide applications (or treatments), is directly proportional to the number of applications (or years) of the herbicide. The cumulative incidence of area with resistance after a continuous usage can be given by the multistage model

$$
P(y)=1-\exp \left(-\sum_{j=1}^{k} \beta_{j} y^{j}\right)
$$

where $y$ is the number of years of application with the herbicide, and $\mathrm{k} \leq \mathrm{m}$ is a known positive integer and $\beta_{j} \geq 0$ for all j. The model in (1) does not assume any background effect which is reasonable because unless treated with the herbicide, selection of a herbicide resistant weed population is unrealistic. Method of maximum likelihood is used to fit the multistage model (1) which is discussed in Guess, H., et. al. (1977). Reference may also be made to Crump, K. (1982) and Portier, C. and Hoel, D. (1984). In (1) when $y=0, P(y)=0$ which means there is no risk of resistance, $P(y)$ ranges between 0 and 1 . As will be seen in section 4 , the area with resistance which has received a specified number of herbicide treatments increases over the years in approximately a straight line. A computer program HRISK written in FORTRAN on VAX fits the model to input data on exposed and resistant areas which has received a userspecified number "a" or more of herbicide treatments with user-specified value of "k", the degree of the polynomial in the model. 


\section{AN EXAMPLE}

The example refers to data on areas under use of a herbicide called "triazine" on corn field in Wisconsin. The herbicide use was first started by farmers in wisconsin corn growing areas in 1961. The rotational pattern ( $P_{i j}{ }^{\prime s}$ ) and areas (in millions of acres) treated with the herbicide for 19 years (1961-1979) are shown in Table 3 .

The first complaint on triazine resistance was registered in 1975, that is, after 14 years of repeated use. It will be of interest to examine here the risk associated with $a=10$ or more of triazine applications over $n=19$ years of continued use. The computer program HRMODEL was run on the data given in Table 3, and the triazine resistant area (in acres) at year 10 (i.e. 1970) of application and after obtained from the program are shown in Table 4.

Detailed computer output is shown in the Appendix. The computer program HRISK was then run on data of Table 4 and the $95 \%$ upper confidence limits on risk of resistance at year 10 and after are given in Table 5 .

Although a risk of $20 \%$ or more is more visible, a warning to the manufacturer of a herbicide producing resistant weed population in a crop should be signalled at a stage when the risk is $10 \%$ or more. At this stage then, farmers can be cautioned to take appropriate measures for protecting their crop yield and quality. Also the manufacturers can protect themselves against unnecessary massive expenses in legal complications.

\section{CONCLUSION}

In this manuscript, an effort has been made to study herbicide resistance problems facing the crop-growers and the herbicide manufacturers through a two-step procedure. In the first step treatment area dynamics modelling is used empirically to arrive at the estimates of areas which have received a certain specified number of herbicide treatment over a specified period of time. A computer program HRMODEL is used for carrying out this step. The data used by HRMODEL are the rotational pattern $\left(P_{i j}{ }^{\prime} s\right)$ and the areas treated with the herbicide for a given number of years. HRMODEL generates input data for the next step which uses the computer program HRISK to evaluate the risk associated with the herbicide used repeatedly for a specified number of times. 
It is the authors' view that treatment area dynamics modelling is not the final solution to the detection of herbicide resistance in various classes of weed population, but an effort to study the resistance in the field. The information obtained through this effort can be utilized to develop effective weed-control management.

[Executable computer program can be obtained from the author by request.]

\section{ACKNOWLEDGEMENT}

The authors are thankful to Maureen Brummer for her painstaking effort in typing and proofreading this paper.

\section{REFERENCES}

Crump,K.(1979): Dose reponse problems in carcinogenesis. Biometrics 35, 157-167.

Gressel,J., and Segel, L.A. (1990): Herbicide rotations and mixtures: Effective Strategies to delay resistance. In M.B. Green, H.M. LeBaron, and W.K. Moberg (eds): Managing Resistance to Agrochemicals American Chemical Society, Washington D.C. pp. 430-458.

Guess,H., Crump,K. and Peto,R. (1977): Uncertainty estimates for low-dose-rate extrapolation of animal carcinogenicity data. Cancer Research $\mathbf{3 7}$, pp. 3475-3483.

LeBaron,H. (1991): Distribution and Serioudness of herbicide resistant weed infectations worldwide. In J.L. Caseley, G.W. Cussans, and R.K. Atkin (eds): Herbicide Resistance in Weeds and Crops. Butterworth/Heinemann Press, oxford, pp. 27-44.

Maxwell, B.D.,Roush, M.L., and Radosevich, S.R. (1990): Predicting the evoluationa dn dynamics of herbicide resistance in weed populations. Weed Technology 4, pp. 2-13. 
Portier, C.J., and Hoel, D.G. (1984): Design of Animal Carcinogenicity Studies for Goodness-ofFit Multistage Models. Fundamental and Applied Toxicology 4, pp. 949-959.

Powels, S.B., Holtum J., Matthews J.M., and Liljegran, D.R. (1990): Herbicide cross resistance annual ryegrass (Lolium rigidum Gaud.) : the search for a mechanism. In M.B. Green, LeBaron, H..M., and W.K. Moberg (eds): Managing Resistance to Agrochemicals. American Chemical Society, Washington D.C., pp. 394-406.

Thill, D.C., Mallory-Smith, C.A., Saari, L.L., Cotterman, J.C., Primiani, M.M., and Saladini, J.L. (1991):

Sulfonylurea herbicide resistant weeds: Discovery, distribution, biology, mechanism, and management. In J.L. Caseley, G.W.Cussans, and R.K. Atkin (eds): Herbicide Resistance in Weeds and Crops. Butterworth/Heineman Press, oxford, pp. 115-128. 


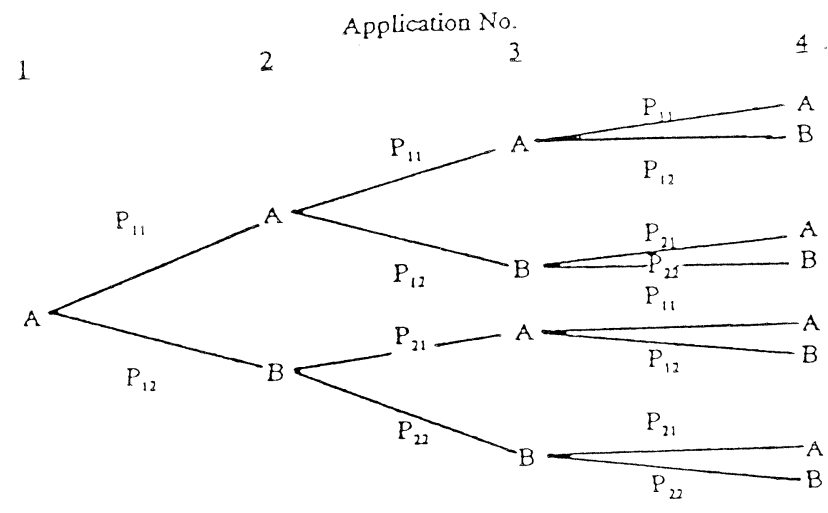

Figure 1

$$
\begin{aligned}
& \text { Area : } \\
& Y_{11}: \\
& Y_{12}=P_{11} Y_{11} \\
& Y_{13}=P_{11}{ }^{2} Y_{11}+P_{12} P_{21} Y_{11}: Y_{12}=P_{11}{ }^{3} Y_{11}+ \\
& P_{12} P_{22} P_{21} Y_{11}: \\
& Y_{23}=P_{11} Y_{22} \\
& \mathrm{Y}_{24}=\mathrm{P}_{11}{ }^{2} \mathrm{Y}_{22}{ }^{+} \\
& P_{12} P_{21} Y_{22}: \\
& Y_{34}=P_{11} Y_{33}
\end{aligned}
$$

Addition:

$$
Y_{22} ; \quad Y_{33} ; \quad Y_{44} ;
$$

Tocal Area:

$$
Y_{11}
$$

$Y_{12}+Y_{22} ;$

$Y_{13}^{r}+Y_{23}+Y_{33}$

$Y_{i d}+Y_{24}+Y_{j 4}+Y_{44}$

$\underline{T a b l e ~} 1$

Distribution of area under herbicide treatment by application number

\section{Application starting Area Added Herbicide Treatment

$\begin{array}{ll}\text { New Area } & \text { Total Area Under } \\ \text { Added } & \underline{\text { Herbicide Treatment }}\end{array}$

$\begin{array}{llll}1 & Y_{11} & 0 & Y_{11} \\ 2 & Y_{12} & Y_{22} & Y_{12}+Y_{22} \\ 3 & Y_{13}+Y_{23}+Y_{34} & Y_{33} & Y_{13}+Y_{23}+Y_{33} \\ 4 & Y_{14}+Y_{24}+Y_{34} & Y_{14}+Y_{24}+Y_{34}+Y_{44}\end{array}$


Table 2

Area Receiving "a" Herbicide Applications in "n' Years

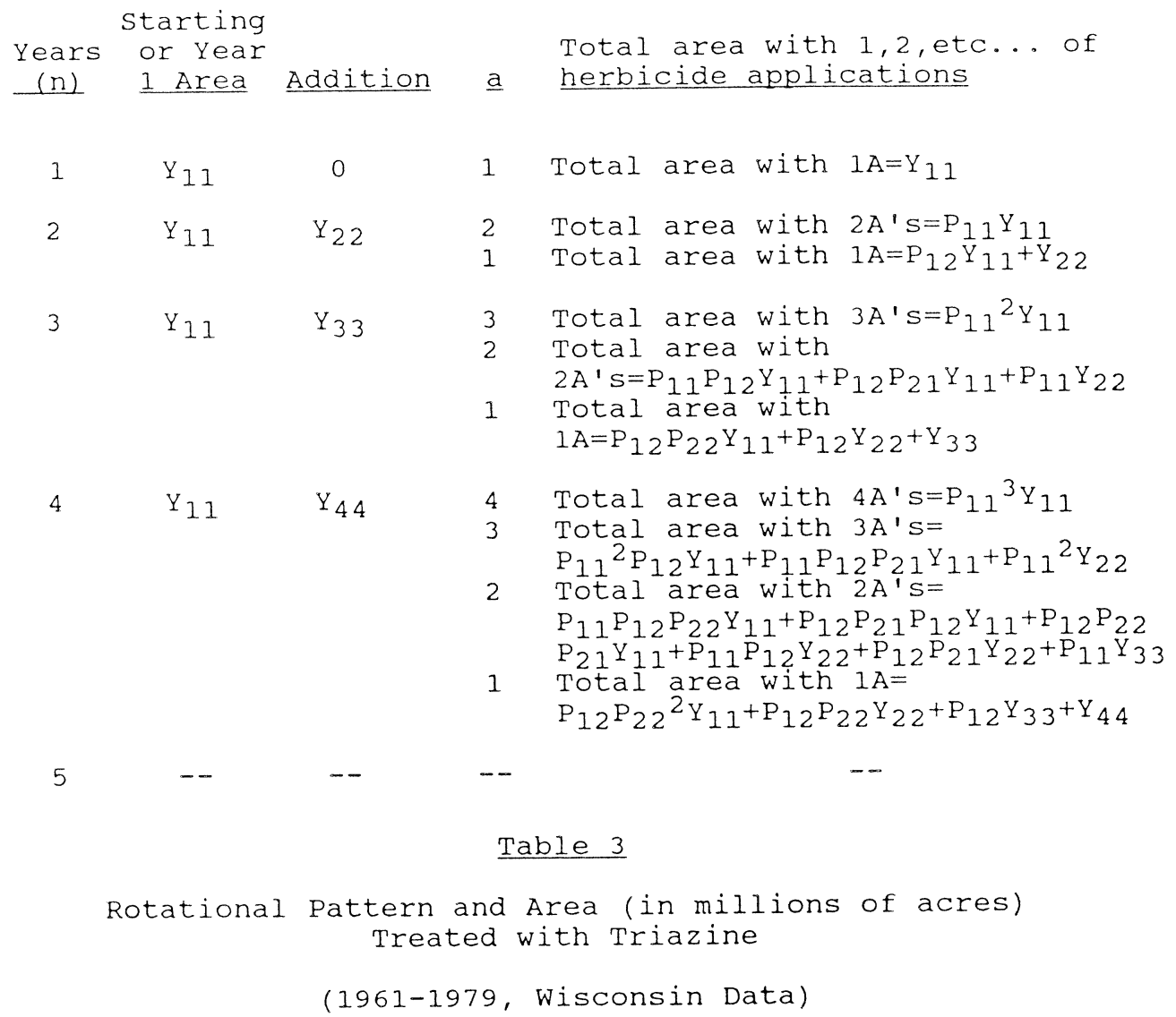

Rotational Pattern

\begin{tabular}{r} 
Year \\
\hline 1 \\
2 \\
3 \\
4 \\
5 \\
6 \\
7 \\
8 \\
9 \\
1 \\
1 \\
1 \\
1 \\
1 \\
1 \\
1 \\
1 \\
1 \\
1
\end{tabular}

Year of Application $\underline{P}_{11}$

1961
1962
1963
1964
1965
1966
1967
1968
1969
1970
1971
1972
1973
1974
1975
1976
1977
1978
1979

0.38

0.38

0.38

0.38

0.38

0.30

0.30

0.30

0.30

0.30

0.28

0.28

0.28

0.28

0.28

0.28

0.28

0.28

0.28
$\underline{\mathrm{P}}_{12}$

0.62

0.62

0.62

0.62

0.62

0.70

0.70

0.70

0.70

0.70

0.72

0.72

0.72

0.72

0.72

0.72

0.72

0.72

0.72
Area (in Millions of Acres) Treated with Triazine $\underline{P}_{21}$ $\underline{P}_{22}$ 0.54 0.54

0.46

0.14 0.54 0.54 0.54 0.46 0.46 0.46

0.46

0.46

0.54

0.54

0.54

0.54

0.54

0.60

0.60

0.60

0.60

0.60

0.60

0.46

0.46

0.46

0.46

0.40

0.40

0.40

0.40

0.40

0.40

0.60

0.40

0.60

0.40

0.40

0.28

0.46

0.64

0.89

1. 10

1.40

1. 60

1.70

1.80

2. 00

2.10

2. 10

2. 10

2. 10

2. 10

2. 10

2. 10

2.10 


\section{Table 4}

Exposure with 10 or More of Triazine Treatment (in acres)

\begin{tabular}{|c|c|c|c|}
\hline $\begin{array}{l}\text { Year } \\
\text { (1) }\end{array}$ & $\begin{array}{l}\text { With constant } \\
\text { Rotational } \\
\text { Pattern as in } \\
\text { Year } 1 \\
(2)\end{array}$ & $\begin{array}{l}\text { With Actual } \\
\text { Rotational } \\
\text { Pattern } \\
\text { (3) }\end{array}$ & $\begin{array}{c}\text { Resistant } \\
\text { Area } \\
\text { (in acres) } \\
(2)-(3)\end{array}$ \\
\hline 10 & 23 & 9 & 14 \\
\hline 11 & 244 & 102 & 142 \\
\hline 12 & 1323 & 588 & 735 \\
\hline 13 & 4928 & 2375 & 2553 \\
\hline 14 & 14527 & 7487 & 6770 \\
\hline 15 & 34268 & 19570 & 14698 \\
\hline 16 & 71474 & 44121 & 27353 \\
\hline 17 & 133315 & 88258 & 45057 \\
\hline 18 & 227262 & 159992 & 67270 \\
\hline 19 & 359738 & 267176 & 92562 \\
\hline
\end{tabular}

Table 5

Risk Associated with 10 or More Triazine Treatments at Year 10 and After

Year

10

11

12

13
95\% Upper Confidence Limit on Risk of Resistance

0.1834 (or 18\% approximately)

0.1998 (or 20\% approximately)

0.2159 (or $22 \%$ approximately)

0.2316 (or $23 \%$ approximately) 


\author{
APPENDIX \\ Computer Output from HRMODEL \\ Constant Rotational Pattern
}

DESIRED MAXIMUM NO. OF YEARS, NM $=19$

\begin{tabular}{|c|c|c|}
\hline $\begin{array}{l}\text { CRES ( In MIIIIOn } \\
\text { OR YEAR 1 TO NM } \\
0.1400 \\
2.2800 \\
2.00002 .1000\end{array}$ & $\begin{array}{l}\text { unft) } \\
0.4600 \\
2.1000\end{array}$ & $\begin{array}{r}\text { TRE } \\
0 \\
2\end{array}$ \\
\hline 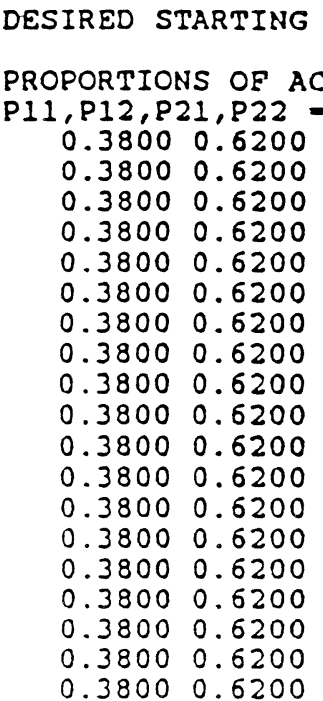 & $\begin{array}{l}0.5 \\
0.5 \\
0.5 \\
0.5 \\
0.5 \\
0.5 \\
0.5 \\
0.5 \\
0.5 \\
0.5 \\
0.5 \\
0.5 \\
0.5 \\
0.5 \\
0.5 \\
0.5 \\
0.5 \\
0.5 \\
0.5\end{array}$ & $\begin{array}{l}0.460 \\
0.460 \\
0.460 \\
0.460 \\
0.460 \\
0.460 \\
0.460 \\
0.460 \\
0.460 \\
0.460 \\
0.460 \\
0.460 \\
0.460 \\
0.460 \\
0.460 \\
0.460 \\
0.460 \\
0.460 \\
0.460\end{array}$ \\
\hline
\end{tabular}

AREA RECEIVING; DESIRED HO. OF TMTMTS, $>-10$

\begin{tabular}{|c|c|c|c|c|c|c|c|c|}
\hline 110. OF TRT. & $\begin{array}{l}10^{Y E} \\
18\end{array}$ & $\begin{array}{l}11 \\
19 \\
\end{array}$ & 12 & 13 & 14 & 15 & 16 & 17 \\
\hline 10 & $\begin{array}{r}23 \text {. } \\
146202 \text {. }\end{array}$ & $\begin{array}{l}235 . \\
214761 \text {. }\end{array}$ & 1222 & 4310. & 11903. & 26979 . & 52817. & 92091. \\
\hline 11 & $\begin{array}{r}0 . \\
57837 .\end{array}$ & 96895. & 97. & 547. & 2096 & 6182 & 15000 。 & 31287. \\
\hline 12 & $\begin{array}{l}0 \\
18031\end{array}$ & $\begin{array}{r}0 . \\
35279\end{array}$ & 3. & 10. & 242. & 995. & 3142. & 8135. \\
\hline 13 & $\begin{array}{l}0 \\
4315\end{array}$ & $\begin{array}{r}0 \\
10139\end{array}$ & 0. & 1. & 16. & 106. & 465. & 1567. \\
\hline 14 & $\begin{array}{r}0 . \\
769 .\end{array}$ & $\begin{array}{r}0 \\
2241\end{array}$ & 0. & 0 . & 0 & 7. & 16. & 215. \\
\hline 15 & $\begin{array}{l}0 . \\
98 .\end{array}$ & 372 & 0. & 0 . & 0. & 0. & 3. & 20. \\
\hline 16 & $\begin{array}{l}0 . \\
8 .\end{array}$ & $\begin{array}{r}0 . \\
14 .\end{array}$ & 0. & 0. & 0. & 0. & 0. & 1. \\
\hline 17 & $\begin{array}{l}0 . \\
0 .\end{array}$ & $\begin{array}{l}0 . \\
4 .\end{array}$ & 0. & 0. & 0. & 0. & 0. & 0. \\
\hline 18 & 0. & 0. & 0. & 0. & 0. & 0. & 0. & 0. \\
\hline 19 & $\begin{array}{l}0 . \\
0 .\end{array}$ & $\begin{array}{l}0 . \\
0 . \\
0 .\end{array}$ & 0. & 0. & 0. & 0. & 0. & 0. \\
\hline TOTAl: & $\begin{array}{r}23 \\
22: 262\end{array}$ & $\begin{array}{r}211 . \\
359738 .\end{array}$ & 1323 & 4920. & $1425 \%$ & 34268. & 71474 & 133315. \\
\hline
\end{tabular}




\section{APPENDIX \\ Computer Output from HRMODEL \\ Actual Rotational Pattern}

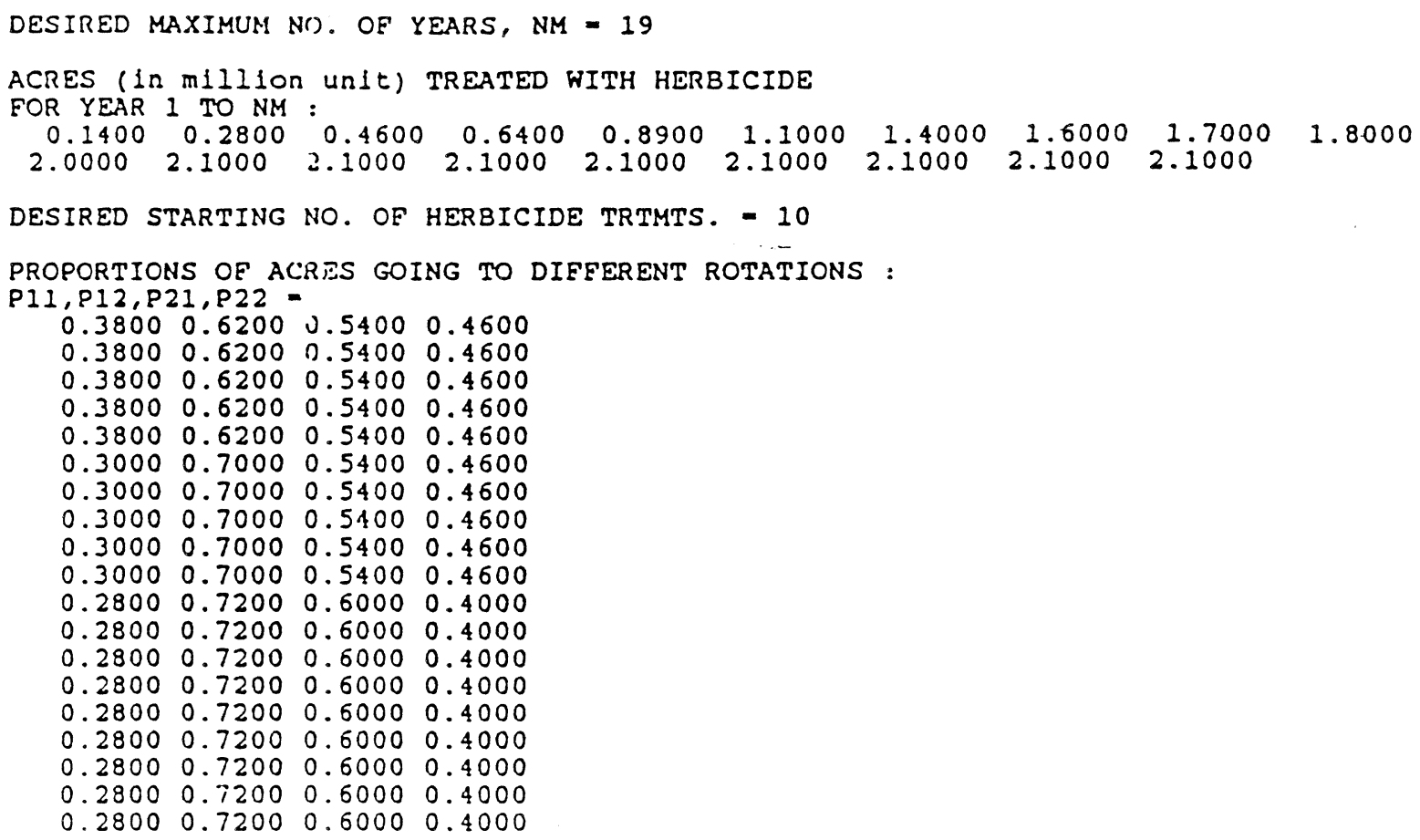

AREA RECEIVIIIC DESIRED HO. OF 'TR'TATS. >-10

\begin{tabular}{|c|c|c|c|c|c|c|c|c|}
\hline Ho. OF TRT. & $\begin{array}{l}10^{Y} \\
18\end{array}$ & $\begin{array}{l}11 \\
19\end{array}$ & 12 & 13 & 11 & 15 & 16 & 17 \\
\hline 10 & $1: 2246$. & $\begin{array}{r}99 . \\
175037 .\end{array}$ & 555. & 2164. & 6549. & 16338 & 31953 & 65974 \\
\hline 11 & $\begin{array}{r}0 \\
30916\end{array}$ & $\begin{array}{r}3 \\
67307\end{array}$ & 32. & 200 & 861. & 2873 . & 7820. & 18141 \\
\hline 12 & $\begin{array}{r}0 . \\
9020 .\end{array}$ & $\begin{array}{r}0 . \\
19750 .\end{array}$ & 1. & 10. & 70. & 331. & 1215. & 3595. \\
\hline 13 & $\begin{array}{r}0 . \\
1594 .\end{array}$ & 1314 & 0. & 0 . & 3. & 21. & 126. & 197. \\
\hline 14 & $\begin{array}{r}0 . \\
198^{\circ}\end{array}$ & $\begin{array}{r}0 . \\
685\end{array}$ & 0. & 0 . & 0. & 1. & B. & 16. \\
\hline 15 & $\begin{array}{r}0 . \\
17 .\end{array}$ & $7 \%$. & 0. & 0. & 0 & 0. & 0. & 3. \\
\hline 16 & $\begin{array}{l}0 . \\
1 .\end{array}$ & $\begin{array}{l}0 . \\
6 .\end{array}$ & 0 . & 0 . & 0 . & 0 . & 0 . & 0. \\
\hline 17 & 0. & $\begin{array}{l}0 . \\
0 .\end{array}$ & 0. & 0. & 0 & 0 . & 0. & 0. \\
\hline 18 & 0. & $\begin{array}{l}0 . \\
0 .\end{array}$ & 0. & 0. & 0 & 0 . & 0 . & 0. \\
\hline 19 & 0. & 0. & 0 . & 0. & 0. & 0. & 0. & 0 . \\
\hline 'JO'TAL: & 159992. & $\begin{array}{r}102 . \\
267176 .\end{array}$ & 588. & 2375 . & 7107. & 19570 & 41121 & 88258 . \\
\hline
\end{tabular}




\section{APPENDIX \\ Computer Output from HRISK}

Risk Assessment

UPPER CONEIDENCE LIMITS ON RISK FOR FIXED YEAR

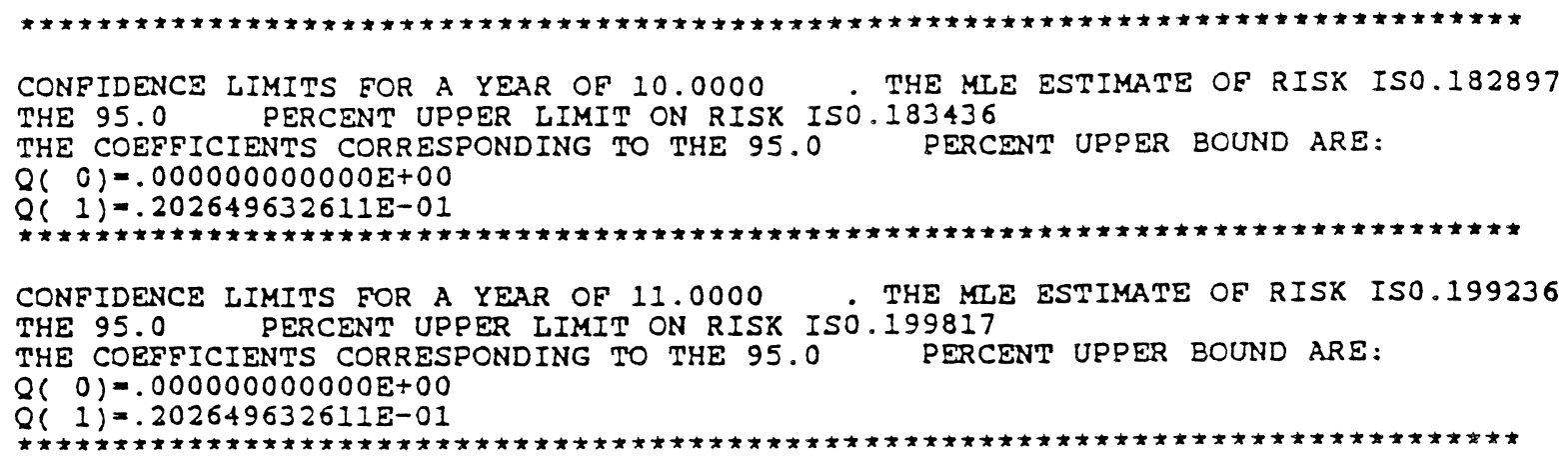

CONFIDENCE LIMITS FOR A YEAR OF 11.0000 . THE MLE ESTIMATE OF RISK ISO.199236 THE 95.0 PERCENT UPPER IIMIT ON RISK ISO.199817

THE COEFFICIENTS CORRESPONDING TO THE 95.0 PERCENT UPPER BOUND ARE:

$Q(0)=.000000000000 \mathrm{E}+00$

$Q(1)=.202649632611 E-01$

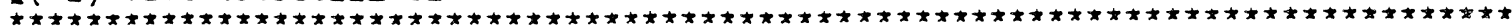

CONFIDENCE LIMITS FOR A YEAR OF 12.0000 . THE MLE ESTIMATE OF RISK ISO.215249 THE 95.0 PERCENT UPPER LIMIT ON RISK ISO.215869

THE COEFPICIENTS CORRESPONDING TO THE 95.0 PERCENT UPPER BOUND ARE:

$Q(0)=.000000000000 \mathrm{E}+00$

$Q(1)=.202649632611 \mathrm{E}-01$

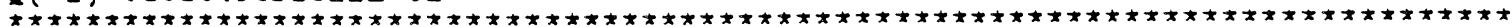

CONEIDENCE LIMITS FOR A YEAR OF 13.0000 . THE MLE ESTIMATE OE RISK ISO.23094I THE 95.0 PERCENT UPPER LIMIT ON RISK ISO.231600

THE COEFFICIENTS CORRESPONDING TO THE 95.0 PERCENT UPPER BOUND ARE:

$Q(0)=.000000000000 E+00$

$Q(1)=.202649632611 E-01$

CONEIDENCE LIMITS FOR A YEAR OF 14.0000

THE MLE ESTIMATE OF RISK ISO. 246319

THE 95.0

PERCENT UPPER LIMIT ON RIS̈̈ ISO.247015

THE COEEFICIENTS CORRESPONDING TO THE 95.0 PERCENT UPPER BCUND ARE:

$Q(0)=.000000000000 E+00$

$Q(1)=.202649632611 E-01$ 